\title{
Proficiencies in Curriculum Aspects among School Improvement Specialist Coaches Plus (Sisc+)
}

\author{
Noel Jimbai Anak Balang*, Zamri Mahamod, Nor Aishah Buang \\ Faculty of Education, University Kebangsaan Malaysia, Malaysia
}

Received January 22, 2020; Revised April 10, 2020; Accepted April 21, 2020

Copyright $\odot 2020$ by authors, all rights reserved. Authors agree that this article remains permanently open access under the terms of the Creative Commons Attribution License 4.0 International License

\begin{abstract}
As being maintained by District Transformation Program 3.0 (DTP 3.0), both skills and knowledge in curriculum aspects are being established by the purposes of School Improvement Specialist Coaches Plus (SISC+). Accordingly, this research endeavoured to recognize the level of competency of SISC+ in curriculum viewpoints. This study adopted a quantitative approach by employing the survey method. Before being examined by utilising SPSS version 23, the data were amassed through a set of questionnaires. Those questionnaires were disseminated to 128 SISC+ throughout the nation. For this research, descriptive statistics concerning frequency, mean score, standard deviation and percentage were employed. With the mean score of $4.23, \mathrm{sd}=0.561$, the results unveiled that SISC+ competency level in curriculum knowledge is at a high standard. From the curriculum viewpoints of the subject being taught, the outcomes of this research proved that SISC+ is accountable and proficient. Besides, the conclusions of this research afforded discernment into the SISC+'s capacity in training teachers in school and their implementation of quality Teaching and Learning (T\&L). Hence, the authority needs to grant support and cooperation to ensure SISC+ remains to be competent in rendering quality coaching to teachers.
\end{abstract}

Keywords School Improvement Specialist Coaches Plus (SISC+), District Transformation Programme 3.0(DTP 3.0), Teaching and Learning (T\&L), Malaysia Education Blueprint 2013-2025 (MEB), Instructional Coaching (ICs)

\section{Introduction}

Osman \& Jaafar (2017) proposed that coaching and knowledge abilities among SISC+ concern contemporary Malaysia's millenary educational remoulding [30]. The
SISC+ must diversify their steering and coaching methods for teachers (Hilmi, Jamil 2017, Radhiah, Brahim \& Sabil 2016) in reconstructing T\&L [23,34]. In order to inspire the teachers to continue adding new knowledge following the position of SISC + as an instructional coach, SISC + must equip themselves with the most advanced curriculum and a variation of the robust pedagogical ingredient (Allen et al, 2011[1]. The most advanced curriculum and pedagogical knowledge designate the high measure of professionalism among teachers (Sarabiah \& Mahamod, 2016; Balang,N, \& Mahamod 2019)[33,5,6]. Working as the impetus for teacher quality, among the hurdles encountered by SISC+ is to ascertain the potency of the coaching manoeuvring (Knight.J, 2019, Joyce \& Showers 2018, Chong \& Mahamod 2017)[17,20,24].

The arena of instructional coaching functions as the catalyst for quality T\&L systems ( Nieto 2014, Nor Asimah 2010, Beth 2009)[23,22,7]. The teachers dramatically improved their proficiency in classroom[21] T\&L since the SISC+ profession begun in 2012 (Saemah \& Mahamod, 2016)[37]. SISC+ facilitates the teachers in the advancement of professionalism to encourage pedagogical capacities and curriculum quality (Knight 2019, Jake \& Knight 2008)[17,19]. Additionally, practical education in the context of coaching entails two parties; principally, the teacher who lead (supervisor/mentors/ coaches) and those who undergo coaching (mentee/coachee/ protégé (Jack \& Chee 2013,Holland \& Adam 2012, Jack \& Knight 2008),[18,14,19]. Teachers must recognise the pedagogical skills of reliable T\&L mechanism[4]. Teachers too must furnish themselves with relevant attitudes, behaviours, skills and knowledge as being recommended by the Planning and Policy Research Division (Hilmi \& Jamil, 2017,Somasundram \& Mahamod 2016)[15,32]. Additionally, in an attempt to satisfy the demands of 21st-century education, SISC+ must render satisfactory coaching programs (Ahmad,S,. et, al 2016, Ahmad \& Mahamod 2015)[2,3]. With this basis, the researchers intend to recognise the competency level of curriculum and 
pedagogical [4] aspect among SISC+ in Sabah and Peninsular Malaysia, which is in accordance with the SISC+ task drive; to administer coaching in curriculum and pedagogical aspects (Zubaidah et al 2018)[3].

In 2012, SISC+ program was introduced to support teachers in improving classroom T\&L with coaching (Balang, N., \& Mahamod 2017, Radhiah, Jamian \& Sabil 2016)[6,28]. Further, the equivalent position performed by the instructional coach who is linked to training teachers to make T\&L more productive and pleasant was introduced too, in other countries ( Desimone \& Pak 2016)[12]. The duties of SISC+ comprise the leading and advising the efficacy of the implementation, coaching teachers on pedagogical skills, practising contemporary curricula and most advanced pedagogy to the classroom as following the District Transformation Programme 3.0 (Malaysia's Education Blueprint (MEB) 2013)[21]. Each District Education Office will be authorised to customise the assistance necessitated by the schools, which covers the hiring of full-time teachers coaches. In low-performing schools, SISC+ will oversee and help teachers (MEB, 2013). It is anticipated that the number of tiers associated in curriculum and pedagogical control will be reduced and continuous professional development (CPDs) will be provided to teachers with SISC+ foundation (Norhasma \& Yusoff, 2019, Bitty \& Pang, 2017) $[37,10]$.

In Malaysian Education Blueprint (MEB) 2013, the SISC+ program covers coaching and mentoring components; and it is believed to be the impetus to promote T\&L. It is feasible by intensifying teachers skills and knowledge in comprehending and executing the most advanced education assessment, pedagogy, curriculum and reforms. SISC+ must perform the task as an instructional coach for the teachers ( Peter et a,.l 2018,Nieto 2014, Syed 2014)[23,23,34].

\section{Materials and Methods}

Among the aspirations of the SISC+ program is the responsibility of presenting teachers with guidance in curriculum, pedagogy and assessment to deliver high-quality teachers who can utilise their expertise in classroom pedagogy (District Transformation Program Management Guide, (DTP), 2017). It means that ideally, the SISC + competency level and coaching practice need to exceed the quality of the teachers they train[21]. Nonetheless, in actuality, DTP asserted that there is SISC + that performs unsuccessfully in mentoring because they are not skilful in curriculum, pedagogy and assessment [21]. Some SISC+ mentors are less accountable to oversee, so it is not very easy to get an authentic view of an aspect that teachers need to develop based on the Teacher Development Plan form. A review of the literature attended by the researchers discovered that pieces of knowledge on the SISC+ program are still lacking[2,6]. Most researchers concentrate plainly on teachers' perceptions of SISC + such as the study managed by Radhiah et al. 2015, Sarabiah \& Mahamod,2016; Balang,N,. \& Mahamod, 2017)[33,6]. Radhiah et al 2016 did studies; Bitty \& Pang (2017); and Zubaidah et al. (2018)[10,29,39] focus only on the purpose of SISC+ in the context of rendering supervision and mentoring to teachers. The research of Tshabala,T, (2013) and Peter et al. (2018)[35,26] conducted in a case study particularly examined the potency of SISC + guidance and function in Kluang, Johor and Tuaran, Sabah. The conclusions of these works of literature positively do not afford a complete summary of SISC + coaching competencies and its best practices. There is only one objective and one research question in this research, which is to identify SISC+ competency in the aspects of curriculum knowledge and what is the SISC + competency in the aspect of curriculum knowledge?

This descriptive study utilised questionnaire instruments distributed through goggle form and developed based on The District Transformation Programme (DTP 3.0 Management Book, Ministry of Education Malaysia (MOE). A total of 23 items for curriculum aspects were reviewed, namely curriculum knowledge were randomly distributed. A total of 128 SISC+ in Sabah and Peninsular Malaysia responded to the questionnaire distributed. The data of the study were analysed employing Statistic for Social Science (SPSS) version 23. The findings of the study involved only descriptive analysis consisted of mean, standard deviation, frequency and percentage. The mean score details were based on Cresswell, 2005 and Ware \& Katsanis, 1994)[11,38].

\section{Results}

Table 1. Respondent Demography

\begin{tabular}{|c|c|c|}
\hline Respondent Demography & $\mathrm{n}=128$ & \\
\hline Gender & Total & Percentage $(\%)$ \\
\hline Male & 52 & 89 \\
\hline Female & 76 & 59.4 \\
\hline \multicolumn{3}{|l|}{ Years As A SISC+ } \\
\hline 2013-2015 & 114 & 89 \\
\hline 2016-2018 & 14 & 11 \\
\hline \multicolumn{3}{|l|}{ Experience as SISC+ } \\
\hline Less than 1 years & 6 & 4.7 \\
\hline 1-3 year & 9 & 7 \\
\hline 4-7 year & 113 & 88.3 \\
\hline \multicolumn{3}{|l|}{ Academic level } \\
\hline Diploma in Education & 2 & 1.6 \\
\hline Degree & 67 & 52.3 \\
\hline Masters & 52 & 40.6 \\
\hline $\mathrm{PhD}$ & 7 & 5.5 \\
\hline
\end{tabular}


Based on the demographics in table 1, 128 respondents answered the questionnaire and found that $52(40.6 \%)$ consisted of male respondents, while $76(59.4 \%)$ were female. The year of appointed as SISC+ was found in 2013, 21 respondents (16.4\%)) Most selected were in 2014, $85(66.4 \%)$ appointed while in $20158(6.3 \%)$ followed in 20164 (3.15), 20178 (6.3\%) and in 20182 $(1.6 \%) .17(13 \%)$ did not have a coaching certificate, and $111(87 \%)$ did not have a certified coach certification from Aminuddin Baki Institute. In terms of experience as a SISC +, it was less than one year, only $6(4.7 \%)$ while 5
(3.9\%) experienced for one year. The highest SISC + experience was 5 , and 6 were $48(37.5 \%)$ while the lowest was SISC + which was only two years $1(0.8 \%)$ The highest teaching experience was that of 21-25 years teaching $38(29.7 \%)$ second-highest teaching experience was 11-15, and 16-20 years were 27 (21.1\%). The highest academic qualification was first degree $67(52.3 \%)$, and the lowest qualification was diploma $2(1.6 \%)$. A total of $49(38.3 \%)$ were regular academic teachers before SISC +, and $45(35.2 \%)$ were excellent teachers.

Table 2. Proficiencies in Curriculum Knowledge

\begin{tabular}{|c|c|c|c|c|c|c|c|c|}
\hline No & Items & $\begin{array}{c}\mathrm{V} . \\
\text { Incompetent }\end{array}$ & Incompetent & $\begin{array}{c}\text { Less } \\
\text { Competent }\end{array}$ & Competent & $\begin{array}{c}\text { V. } \\
\text { Competent }\end{array}$ & Mean & Sd \\
\hline B1 & $\begin{array}{l}\text { Knowing the Curriculum } \\
\text { and Assessment Standard } \\
\text { Document (DSKP) of the } \\
\text { Primary School } \\
\text { Curriculum (KSSR) and } \\
\text { the High School Standard } \\
\text { Curriculum (KSSM) are } \\
\text { well-guided subjects. }\end{array}$ & $\begin{array}{c}1 \\
(0.8)\end{array}$ & $\begin{array}{c}0 \\
(0.0)\end{array}$ & $\begin{array}{c}8 \\
(6.3)\end{array}$ & $\begin{array}{c}53 \\
(41.4)\end{array}$ & $\begin{array}{c}66 \\
(51.6)\end{array}$ & 4.43 & .684 \\
\hline B2 & $\begin{array}{l}\text { Understand the KSSR } \\
\text { and KSSM subject matter } \\
\text { well }\end{array}$ & $\begin{array}{c}1 \\
(0.8)\end{array}$ & $\begin{array}{c}0 \\
(0.0)\end{array}$ & $\begin{array}{c}6 \\
(4.7)\end{array}$ & $\begin{array}{c}54 \\
(42.2)\end{array}$ & $\begin{array}{c}67 \\
(52.3)\end{array}$ & 4.45 & .662 \\
\hline B4 & $\begin{array}{l}\text { Can provide a description } \\
\text { of the skills elements } \\
\text { contained in the KSSR } \\
\text { and the KSSM subject } \\
\text { matter that are guided }\end{array}$ & $\begin{array}{c}1 \\
(0.8)\end{array}$ & $\begin{array}{c}0 \\
(0.0)\end{array}$ & $\begin{array}{c}13 \\
(10.2)\end{array}$ & $\begin{array}{c}54 \\
(42.2)\end{array}$ & $\begin{array}{c}60 \\
(46.9)\end{array}$ & 4.34 & .726 \\
\hline B6 & $\begin{array}{l}\text { Know the syllabus of a } \\
\text { well-conducted subject }\end{array}$ & $\begin{array}{c}1 \\
(0.8)\end{array}$ & $\begin{array}{c}0 \\
(0.0)\end{array}$ & $\begin{array}{c}13 \\
(10.2)\end{array}$ & $\begin{array}{c}52 \\
(40.6) \\
\end{array}$ & $\begin{array}{c}62 \\
(48.4) \\
\end{array}$ & 4.36 & .729 \\
\hline B8 & $\begin{array}{l}\text { Planning the curriculum } \\
\text { activities of the subject } \\
\text { subject }\end{array}$ & $\begin{array}{c}3 \\
(2.3)\end{array}$ & $\begin{array}{c}6 \\
(4.7)\end{array}$ & $\begin{array}{c}17 \\
(13.3)\end{array}$ & $\begin{array}{c}56 \\
(43.8) \\
\end{array}$ & $\begin{array}{c}46 \\
(35.9)\end{array}$ & 4.06 & .945 \\
\hline B10 & $\begin{array}{l}\text { Implement an } \\
\text { intervention program that } \\
\text { is within the capacity of } \\
\text { the Guided Teacher (GT) }\end{array}$ & $\begin{array}{c}0 \\
(0.0)\end{array}$ & $\begin{array}{c}0 \\
(0.0)\end{array}$ & $\begin{array}{c}9 \\
(7.0)\end{array}$ & $\begin{array}{c}57 \\
(44.5)\end{array}$ & $\begin{array}{c}62 \\
(48.4)\end{array}$ & 4.41 & .621 \\
\hline B12 & $\begin{array}{l}\text { Resolve problems related } \\
\text { to curriculum programs at } \\
\text { district level }\end{array}$ & $\begin{array}{c}1 \\
(0.8)\end{array}$ & $\begin{array}{c}7 \\
(5.5)\end{array}$ & $\begin{array}{c}25 \\
(19.5)\end{array}$ & $\begin{array}{c}59 \\
(46.1)\end{array}$ & $\begin{array}{c}36 \\
(28.1)\end{array}$ & 3.95 & .877 \\
\hline B14 & $\begin{array}{l}\text { Evaluate the effectiveness } \\
\text { of curriculum programs } \\
\text { conducted at the district } \\
\text { level }\end{array}$ & $\begin{array}{c}2 \\
(1.6)\end{array}$ & $\begin{array}{c}6 \\
(4.7)\end{array}$ & $\begin{array}{c}24 \\
(18.8)\end{array}$ & $\begin{array}{c}59 \\
(46.1)\end{array}$ & $\begin{array}{c}37 \\
(28.9)\end{array}$ & 3.96 & .900 \\
\hline B16 & $\begin{array}{l}\text { Guiding GT oversees the } \\
\text { curriculum process } \\
\text { created by the committee }\end{array}$ & $\begin{array}{c}1 \\
(0.8)\end{array}$ & $\begin{array}{c}3 \\
(2.3)\end{array}$ & $\begin{array}{c}16 \\
(12.5)\end{array}$ & $\begin{array}{c}65 \\
(50.8)\end{array}$ & $\begin{array}{c}43 \\
(33.6)\end{array}$ & 4.14 & .781 \\
\hline B18 & $\begin{array}{l}\text { Provides up-to-date } \\
\text { curriculum input to } \\
\text { enhance TnL }\end{array}$ & $\begin{array}{c}0 \\
(0.0)\end{array}$ & $\begin{array}{c}1 \\
(0.8)\end{array}$ & $\begin{array}{c}6 \\
(4.7)\end{array}$ & $\begin{array}{c}55 \\
(43.0)\end{array}$ & $\begin{array}{c}66 \\
(51.6)\end{array}$ & 4.45 & .626 \\
\hline B20 & $\begin{array}{l}\text { Guiding GT identifies the } \\
\text { use of teaching resources } \\
\text { that promote HOTS based } \\
\text { on the KSSR and KSSM } \\
\text { curriculum }\end{array}$ & $\begin{array}{c}0 \\
(0.0)\end{array}$ & $\begin{array}{c}0 \\
(0.0)\end{array}$ & $\begin{array}{c}8 \\
(6.3)\end{array}$ & $\begin{array}{c}62 \\
(48.4)\end{array}$ & $\begin{array}{c}58 \\
(45.3)\end{array}$ & 4.39 & .605 \\
\hline
\end{tabular}


What is the SISC+ competency in the aspect of curriculum knowledge?

Descriptive statistics concerning mean, standard deviation, have been used to determine SISC+ competency in curriculum knowledge. Based on table 2, the overall mean score for SISC+ competency level in curriculum knowledge was very high $(\mathrm{M}=4.23 . \mathrm{SD}=.561)$. Based on the items given, items B1, B2, B4, B6, B10 and B18 are scoring very high mean for the SISC+ competency level. Whereas for items B8, B12, B14, B16 and B20, the mean score is only competent.

\section{Discussion}

The conclusions reveal that SISC + competency level in the curriculum is high. It is good that SISC+ can maintain the momentum of excellence in providing quality guidance to teachers. Overall, this strengthens the conclusions of Radhiah et al. 2016, Sarabiah \& Mahamod,2017,Balang, N, \& Mahamod (2019) that SISC+ demands strong curriculum and pedagogical skills in order for teachers to have high confidence in SISC+'s capability to provide guidance $[28,33,6]$. To strengthen SISC+ professionals, the conclusions of Hilmi and Jamil (2017) research support that the quality of mentoring is one level or the ability of SISC+ to guide quality coaching practice [15]. It is relevant that the KPM institute this position with a focus on guiding curriculum, pedagogy and assessment [21]. Through robust coaching systems, schools under band five can be assisted, and teachers will be granted guidance in terms of ideas, concepts, organisations, procedures, teaching procedures of the 21st century (Bradley,W,2017)[9]

Inferences from the research also uncovered that SISC+ pedagogical knowledge was at a high level. It has implications for the planning and implementation of the SISC + program. The judgments of this research are in line with Hilmi \& Jamil's 2017 study which asserted that SISC + needs to focus on the fitness of leadership, timeframe, area of guidance and facilities in the guidance discipline [15] and declared that the suitability of a mentoring session is essential throughout the mentoring session.

According to Radhiah et al. (2016), the components of teachers and schools are the spur for school potency and student accomplishment [28,29]. Deussen,T., et al (2018) argued that SISC + professionals are not merely relating to the professional nature of the educational organisation but are exhaustive[13]. Being a great quality SISC+, it unites three fundamental ingredients, specifically curriculum knowledge, pedagogy and assessment, forming a more credible SISC+ and recognised as a mentor (Deussen,T., et al 2018)[13]. For valuable leadership, SISC+ must employ the best skills to make the knowledge shift easily. Employing values in coaching practice is also indispensable for SISC + to be an exemplary model for teachers (Knight \& Jake, 2007)[16]
Nevertheless, by holding instructional coaches in schools, it advances students' accomplishment but at an insignificant level. It is because, there is a shortage of data connecting coaching immediately to innovations in teacher preparation and student accomplishment, weak regularity in the purpose of SISC+, inadequate documentation of what happens throughout coaching communications, and an expert advancement is a new event (Borman,J.F 2006)[8]. Meantime, Duessen, (2018) discovered that instructional coaches serve differently in schools and completed extra duties than just coaching [13]. Also, SISC+ plays its role as instructional coaching partially during working weeks. There are insufficient records on what these instructional coaches do and ways in which they engage with teachers that may result in student's progress and attainment (Knight 2019, Peter et al, 2018)[17,26]

In an attempt to produce more productive SISC+, they must become proficient in questioning abilities, knowledge quality, coaching methodology, self-directed professional learning, contemporary curriculum, pedagogical capabilities, learning interest and present a diversity of workshops and courses to establish their characters in terms of communication (Thomas, 2015)[36]. Reflections on the purpose and efficacy of SISC + leadership should be administered to comprehend Malaysia coaching further. The research on this particular domain would grant practical knowledge for parents, holistic community and the Ministry of Education. Besides, it serves as an impetus for educators in schools and education discipline to keep abreast and endeavour solutions for a more satisfactory method. (Desimone \& Pak 2016, Shaun, 2009)[12,31]. It is observed that when SISC+ is adroit with significant components such as curriculum, content standards, and everyday teachings, it is undoubtedly to be fully realised. Such a systematic system allows SISC+ to guide teachers with more specific courses, in comparison with to let the teacher blend innovative approaches and methods into their pedagogy. In fact, it is proven that the achievement of SISC+ is correlated to the curriculum productiveness that the teachers were utilising (Balang,N,. \& Mahamod, 2019, Zubaidah et al 2018) and the content and standards that teachers were teaching. [6,39]

\section{Conclusions}

SISC+ refers to the people who are full-time professional developers, positioned in districts or on-site in schools[17]. SISC+ operates with teachers to assist them in consolidating research-based instructional systems. When SISC+ engages with students, they aim to illustrate brand-new dominant modes to teachers. Working as executive coaches, SISC+ has to be proficient in cooperating with teachers goals and learning their clients' demands[17,18]. It is necessary so that they can assist teachers in designing a plan for accomplishing their 
professional intentions. SISC + is a manifestation of a repertoire of exceptional communication abilities and can sympathise, hear, and constitute bonds and assurance[21,25]. Additionally, similar to cognitive coaches, SISC+ have to be extremely skilful at improving teachers' reflection about their classroom methods. Ultimately, similar to literacy coaches, SISC+ have to recognise a large number of scientifically validated instructional applications. SISC+ focuses on a more extensive expanse of instructional issues, shares a diversity of powerful exercises that present content improvement, particular teaching applications, classroom administration, or formative evaluation. In order words, the SISC+ cooperates with teachers so they can pick and perform research-based interventions to support students to study more efficiently (Knight 2019, Holland \& Adam 2012) $[17,14]$

The researchers have examined ways in which SISC+ through instructional coaching is harmonious with research-based concepts of active professional growth, particularly with its realisation of five crucial characteristics of competencies[21]. These competencies are span, consistency, progressive education, collective partnership and content focus. The researchers too recognised the inclination for irregularity and proposed its reasons to be alleviated. The readers should not be astounded to learn the influence and advantages of SISC+ instructional coaching. Ergo, more extended empirical studies must be administered to resolutely suggest coaching as a relevant professional advancement chance for teachers to advance their T\&L ( Wan Norhasma \& Nurahimah, 2019, Richard, 2016, Ware \& Katsanis, 2015, Shaun, 2009)[37,27,38,31].

\section{Acknowledgements}

I would like express my gratitude and appreciation to my supervisors Prof Dr Haji Zamri Mahamod and Prof Dr Nor Aishah Buang from Faculty of Education, National University of Malaysia for their supports and guidance.

\section{REFERENCES}

[1] Allen,J.P., Pianta, R.C., Gregory. A., Mikami,A.Y.,\& Lun,J. An interaction-based approach to enhancing secondary Schools instruction and student achievement. Journal of Science Education, Vol, 333,,No,6045,1034-1037, 2011.

[2] Ahmad,S.M.,Radzuwan,A.R.,Kamariah,Y.,\& Safawati, B.Z.(2016). Exploring The School Improvement Specialist Coaches' Experience in Caoching English Language Teachers. International Arab World English Journal(AWEJ) Vol, 7, 243-255, 2016.
[3] Ahmad, A,. \& Mahamod, Z. Skills Level of Secondary Malay's Language Teacher Implementing the school Based Assessment Based on Gender, Options and Teaching Experince. Journal of Educational Malay's Studies, Vol.1,No.6, 66-72, 2015.

[4] Annenberg Institute For School Reform, Instructional Coaching, Professional Development Strategies That Improve Instruction.Online available from http://www.annenberginstitute.org/pdf/Instructinallcoachin g.pdf.2015.

[5] Balang,N,.J. School Improvement Specialist Coaches Plus (SISC+): An Argumentative Analysis. Journal of Education, Kota Samarahan Kuching, Teachers Training Institute, Vol 1, No. 1; 48-71,2017.

[6] Balang,N,J, \& Mahamod, Z. The Acceptance of School Improvement Specialist Coaches Plus (SISC+) Coaching and mentoring Amongst Malay's Language Teacher. National Conference on Educational Research, Universiti Kebangsaan Malaysia, 280-291,2017.

[7] Beth B,Chyran,G,. Coaching For Instructional Improvement: Theme in Research and Pratice.Online available fromhttp://www.k12leadership.org/sites/default/f iles/kappan-article.pdf.2009

[8] Borman, J.,Feger,S. Instructional Coaching: Key Themes From Literature. Online available from http://www.brown.edu/academics/education-alliance/sites/ brown.edu.academic.education-alliance/files/publication/T L-Coaching- Lit-review.pdf. 2006

[9] Bradley Williams. High Impact Instruction. Upper Saddle River, New Jersey Prentice Hall.2017.

[10] Bitty Ansawi \& Pang,V,. The Relationship Between Professional Learning Community And Lesson Study: A Case Study In Low Performing Schools in Sabah,Malaysia, Vol. 9, No.13, 63-70.2017.

[11] Creswell, J.W.,. Research Design: Qualitative, Quantitative and Mixed Methods Approches. Second Edition. Thousand Oaks Sage,London, 2005.

[12] Desimone, L., Pak,K. Instuctional Coaching as High-Quality Professional Development. The College of Education and Human Ecology., The Ohio State University. 2016

[13] Deussen, T., Coskie, T., Robinson, L.,\& Autio,E."Coach"can mean many things: Five categories of literacy coaches in Reading First (Issues \& Answers Report, REL 2007-No 005). Washington, DC: Department of Education, Institute of Education Sciences, National Center for Education Evaluation and Regional Assistance Northwest. Online available from http://ies.ed/gov/ncee/edlabs/regions/northwest/pdf/REL_2 007005.pdf, 2018.

[14] Holland.M \& Adam Mitchell,. A. Teachers for Professional Growth: Creating A Culture of Motivation and Learning, Corwin Press Inc. California , 2012.

[15] Hilmi.A, \& Jamil.,A,(2017). Teachers Perception Towards School Improvement Specialist Coaches Plus (SISC+).Conference on Trans disciplinary Education (STEd2017) (pp.198-205). Online available :https://sted20 17.files.wordpress.com/2016/12/1-24-mohd-hilmi-anwa-ja 
mil-ahmad.pdf

[16] Knight,J,Jake.C,.Paper: Studying The Impact Of Instructional Coaching. Online available from http://www.instructionalcoach.org/research/tools/paper-stu dying-the-impact-of-instrutional-coaching, 2007.

[17] Knight,J. Instructional Coaching For Implementing Visible Learning: A Model For Translating Research Into Practice; Corwin: Thousand Oaks, CA, USA, 2019.

[18] Jack, C,.\& Chee,W. Coaching and Mentoring. A Handbook For Coaches. Columbia University Press. London, 2013

[19] Jake,C, Knight,J. Research On Coaching. Online available from

http://www.instructionalcoach.org/images/download/resear ch-pubs/corntt-knight- 2008.pdf.2008

[20] Joyce \& Shower. Instruction Supervision: A Behaviour System. Boston: Allyn and Bacon, New York, 2010.

[21] Malaysia's Education Blueprint. National Key Results Area (NKRA), Online available from http://www.sumberpemandu.gov.my, 2013.

[22] Nor Asimah. The Effectiveness of Coaching Teachers in Sultan Idris Education University, Proceeding of the 4th International Conference on Teacher Education, Bandung, Indonesia, 22-27,2010.

[23] Nieto, R.J.;Rirth. Clinical Supervision. Houghton Mifflin Press, Boston, 2014.

[24] Ong Sze Chong \& Zamri Mahamod. Characteristic of Teaching and Learning Amongst Malay's Language Excellent Teachers in Secondary Schools in Sarawak, Conference on Postgraduate, Faculty of Education Fifth Edition,Universiti Kebangsaan Malaysia, 30-36, 2016.

[25] Osman.,R., Jaafar.,M.,F., Professional Learning Community as a Practises: A survey on Excellent, Moderate and Lowest Schools in Malaysia, Journal of Research in Teacher Education, Vol,6, No.7,50-65,2017.

[26] Peter.,S.,D., Taylor.,M.,B., Burnham., B., Shock., R. (2018). Reflective Coaching Conversations: A Missing Piece. White Plains, NY: Longman.

[27] Richard Luecke. Coaching And Mentoring. Harvard Business School Press. Boston Massachusetts, 2016.

[28] Radhiah, R,. Jamian, A, R, \& Sabil M,A,(2016). Knowledge and Understanding of Malay's Subject amongst School Improvement Specialist Coaches Plus (SISC+).International Journal of Education and Training (InJET), University Putra Malaysia, Vol. 2, No. 2, 1-9, 2016.

[29] Radhiah, R,. Brahim, M, \& Sabil, M, A,.(2016). Online available: http://ejournals.ukm.my/jpend/article/vie w/16017.

[30] Saemah, R, \& Mahamod,Z. Creativity in Teaching and Learning. Citra Publisher, Universiti Kebangsaan Malaysia, Selangor, 2016.

[31] Shaun. A \& Harbour. M. The Coaching Toolkit. Sage Publication. London.2009
[32] Somasundram,.B \& Mahamod,. Z. Post Graduate Educational Conference of Malay's Literature Fifth Edition. Universiti Kebangsaan Malaysia. 69-74. 2016

[33] Sarabiah, J.\& Mahamod, Z.Tanggapan, Amalan dan Keberkesanan Bimbingan Pegawai SISC+ dari Perspektif Guru Bahasa Melayu. Prosiding Seminar Pascasiswazah Pendidikan Kesusasteraan Melayu Kali Kelima. Fakulti Pendidikan, Universiti Kebangsaan Malaysia,2016

[34] Syed Ismail Syed Mustapa. Online available from: https://www.ukm.my/jurfpend/jurnal38/7SYEDISMAILS YEDMUSTAPA.pdf.

[35] Tshabalala,T. Online available from: https://www.ijsse.com/sites/default/files/issues/2013/v4il/p aper/Paper-3.pdf

[36] Thomas Neagley,(2015). Hand Book for Effective Supervision of Instruction. (3rd edition). p.2-3. New Jersey: Prentice- Hall, Inc.

[37] Wan Norhasma \& Nurahimah Mohd Yusoff,(2019). SKPMg2 (Standard 4) As Tools To Upgrade Teachers Teaching Quality. Online available from: http://www.jerisjournal.com

[38] Ware \& Kitsanis. E.D. Supervising Instruction: Differentiating for Teacher Success. Norwood, Christopher Gordon Publisher, Norway, 2015.

[39] Zubaidah,B,.Yamat, H, \& Wahi, W,. School Improvement Specialist Coaches Plus (SISC+) Teacher Coaching In Malaysia: Examining The Studies. Online available from: http://www.ijcar.net.pdf 